\title{
Reduced Cytokine Secretions by LAK Cells of Pulmonary Tuberculosis Patients in Response to Tumor Targets In Vitro
}

\author{
R. NIRMALA, R. MATHEW, and P.R. NARAYANAN
}

\begin{abstract}
Activation of macrophages and other immune components to release a series of proinflammatory cytokines is one of the first events in innate resistance to intracellular infections. Severe manifestations of tuberculosis (TB) could be caused by alterations in the balance of these cytokines. In this study, lymphokine-activated killer (LAK) cells of TB patients and normal individuals were generated by stimulation with cytokines in vitro. The LAK cells of both groups were further triggered with allogeneic tumor targets. Cytokines interferon- $\gamma$ $($ IFN- $\gamma$ ), tumor necrosis factor- $\alpha$ (TNF- $\alpha$ ), and granulocyte-macrophage colony-stimulating factor (GM-CSF) were estimated in the supernatants generated in the two groups. The aim was to see if infection with TB influenced the secretory capacity of the immune cells in vitro. Reduced cytokine profiles were observed in TB patients, indicating defective interactions between patient effector cells with allogeneic transformed cells compared with normal individuals. Partial restoration of IFN- $\gamma$ production was seen with a combination of cytokines interleukin-2 (IL-2) and IL-12 in TB patients. Based on the in vitro observations, we hypothesize that in vivo also there is diminished immune cell activation of effector cells in response to the presence of infected macrophages. This probably leads to a diminished secretory function that can be corrected by the use of such cytokines as IL-2 and IL-12. The effector populations of TB patients are probably in a state of target-induced anergy, allowing the bacteria to thrive, and immunomodulatory cytokines that improve the host immune response toward countering mycobacterial infection.
\end{abstract}

$\mathbf{T}$ UUBERCULOSIS (TB) REMAINS AN IMPORTANT CAUSE of morbidity and mortality worldwide, with one third of the population infected with the tubercle bacillus. ${ }^{(1)}$ By far the most important factor that determines whether infection will ultimately lead to disease is the adequacy of the host immune response in general and the cell-mediated immune response in particular. Proof of this lies in the fact that the risk of TB is linked to cellular immunodeficiency conditions associated with age, immunosuppressive drugs, and other diseases, such as diabetes, malignancies, silicosis, renal failure, and most notably AIDS. ${ }^{(2)}$ For a successful protective immune response, the network involving infected macrophages, activated $\mathrm{T}$ lymphocytes, activated natural killer (NK) cells, and their respective cytokines needs to be well coordinated. ${ }^{(3)}$ The recent outbreak of multidrug-resistant TB underscores the need for novel approaches to treat and prevent $\mathrm{TB}$, including the use of immunotherapeutic modalities that enhance the antimycobacterial defense. Development of such strategies requires a detailed study of the cytokines that mediate resistance toward TB. ${ }^{(4,5)}$

Macrophage interleukin-12(IL-12) production was shown to be prominent in tuberculous lymph nodes, and it is known that IL-12 is a central initiator of the local Th1 response, ${ }^{(6)}$ as it is responsible for induction of interferon- $\gamma($ IFN- $\gamma$ ), tumor necrosis factor- $\alpha$ (TNF- $\alpha$ ), granulocyte-macrophage colony-stimulating factor (GM-CSF), IL-3, IL-8, and IL-2 cytokines from $\mathrm{T}$ and NK cells. ${ }^{(7-9)}$ It is known that in vitro culture of human peripheral blood lymphocytes (PBL) in IL-2 results in the generation of cytotoxic cells that lyse autologous and allogeneic tumor targets through release of a number of well-characterized slow-acting cytokines, such as natural killer cytotoxic factor (NKCF), IFN, TNF, and lymphotoxin, that are cytostatic or cytotoxic for tumors. This has been referred to as the lymphokineactivated killer (LAK) phenomenon, with NK cells being the major contributors to LAK activity. ${ }^{(10-15)}$ Similarly, it is pos-

Tuberculosis Research Centre, Chetput, Chennai-600 031, India. 
sible that infected monocytes likewise initiate a cascade of cytokine release from the LAK cells generated in vivo under infectious conditions through release of such cytokines as IL-2. On the basis of this model, experiments were designed to see if the potential problem in the host immune response of the TB patient was a defect in the trigger of important cytokines by the patient's LAK cells. The allogeneic cell line U937 served as a tumor target model to trigger the LAK cells generated in vitro in the patient group and was compared with LAK cells of normal individuals. As human infection with Mycobacterium tuberculosis displays a spectrum of manifestations that reflect the efficacy of the immune response, ${ }^{(16)}$ understanding the mechanisms of LAK cell-mediated cytokine secretions in vitro will provide an insight into how the production of cytokines may be regulated in vivo.

LAK cells were generated by the method of Grimes and Hersh's group. ${ }^{(17)}$ Eight patients smear and culture positive for TB and eight normal individuals (25-50 years of age) were included in the study. Peripheral blood mononuclear cells (PBMCs) from both groups were obtained by the standard Ficoll-Hypaque (Sigma Chemical Co., St. Louis, MO) density gradient centrifugation method and adjusted to $10 \times 10^{6}$ cells/ml in complete RPMI 1640 culture medium supplemented with $5 \%$ heat-inactivated fetal bovine serum (FBS), $2 \mathrm{mM}$ glutamine, $5 \mathrm{mM}$ HEPES, $5 \times 10^{-5} \mathrm{M}$ 2-ME, $100 \mathrm{U} / \mathrm{ml}$ penicillin, and $20 \mu \mathrm{g} / \mathrm{ml}$ gentamicin at $\mathrm{pH}$ 7.2-7.4 (Sigma Chemical Co.). PBMC $\left(2.5 \times 10^{6}\right)$ were cultured in 12 -well tissue culture plates (Costar, Cambridge, MA) in complete RPMI medium in the presence of IL-2 (100 U/10 6 cells), IL-12 (50 U/10 6 cells), and IL-2 + IL-12 (50 U + $10 \mathrm{U} / 10^{6}$ cells $)$ for 3 days at $37^{\circ} \mathrm{C}$ in a humidified $5 \% \mathrm{CO}_{2}$ atmosphere. rIL-2 was purchased from Genzyme (Cambridge, MA), and rIL-12 was a kind gift from G. Trinchieri (Philadelphia, PA). At the end of the incubation period, nonadherent cells and the supernatants were collected and centrifuged at $1800 \mathrm{rpm}$. The supernatants were gently aspirated and stored at $-70^{\circ} \mathrm{C}$ in small aliquots, taking care to avoid repeated freeze-thaw cycles.

After removal of the supernatants of the LAK cells, the effector cells (E) were thoroughly washed and resuspended in complete medium. They were then mixed with $5 \times 10^{6}$ U937 cells (tumor target cell line [T] obtained from the National Facility for Animal Tissue and Cell Culture, DBT, Pune, India). The E:T ratio was maintained at 1:2, and the mixture was incubated for a further period of $18 \mathrm{~h}$. The mixed population was harvested, and the supernatants were gently collected and stored at $-70^{\circ} \mathrm{C}$ in small aliquots. Appropriate controls were maintained.

The LAK supernatants collected before and after coculturing with tumor targets were analyzed by enzyme-linked immunosorbent assay (ELISA) for the presence of the cytokines IFN- $\gamma$, TNF- $\alpha$, and GM-CSF according to the standard protocol using ELISA reagents (Endogen, Boston, MA). The results were analyzed using Student's $t$-test.

In Figure 1, cytokine production by LAK cells in normal individuals and TB patients is illustrated. IL-2 and IL-12 were potent inducers of IFN- $\gamma$, producing $5000 \pm 2000 \mathrm{pg} / \mathrm{ml}$ and $8000 \pm 2000 \mathrm{pg} / \mathrm{ml}$ IFN- $\gamma$, respectively, in normal individuals IL-12 appears to be more potent than IL-2, and the two cytokines together further enhance the production of IFN- $\gamma$, up to $13000 \pm 6500 \mathrm{pg} / \mathrm{ml}$ in normal individuals, compared with either of them alone $(p<0.01)$. In the case of TB patients, IFN- $\gamma$ levels in response to IL-2 and IL-12 were around $4000 \pm 2000$ and $7000 \pm 1000 \mathrm{pg} / \mathrm{ml}$, respectively. The IFN- $\gamma$ level was $8000 \pm 1000 \mathrm{pg} / \mathrm{ml}$ in response to the two cytokines together. These results indicate that TB patients also produce IFN- $\gamma$ in response to IL-2/IL-12 stimuli, but the levels of IFN- $\gamma$ were significantly reduced $(p<0.05)$ compared with normal individuals It was found that in normal individuals, an average of $8000 \mathrm{pg} / \mathrm{ml}$ IFN- $\gamma$ was produced in response to prestimulation with IL-2 alone, and $16,000 \mathrm{pg} / \mathrm{ml}$ was produced in response to IL-2 + IL12 , but when IL-12 alone was used, the response was not so dramatic. The levels dropped to $2500 \mathrm{pg} / \mathrm{ml}$, indicating that by itself IL-12 was unable to prestimulate the cells to produce IFN- $\gamma$ in response to the target cells. Similarly, TB patients also showed reduction in IFN- $\gamma$ levels when triggered with tumor targets when prestimulated with IL-12 alone. IL-2 also failed to prestimulate the cells to produce IFN- $\gamma$ in response to tumor targets, in contrast to normal individuals. However, the response to a combination of IL-2 and IL-12 was found to be $7000-9500 \mathrm{pg} / \mathrm{ml}$. The results indicated that there was a significant reduction in cytokine secretion by TB patients in response to tumor targets, compared with normal individuals $(p<0.001)$. It follows that IL-2 and IL-12 are potent inducers of IFN- $\gamma$, acting in a synergistic manner. Patients respond well to a combination of IL-2 and IL12 prestimulation, although the response was significantly less than that in normal individuals. IFN- $\gamma$ production is probably one of the most physiologicallyrelevant functions of IL-12, and many of IL-2 in vivo effects are mediated, at least in part, through IFN$\gamma \cdot{ }^{(18)}$ It is well known that IL-2 stimulates the secretory activities of cytotoxiclymphocytes. IL-12 also strongly synergizes with other stimuli in inducing maximum levels of IFN- $\gamma$ production and is a known Th1 inducer. These observations have been corroborated in the present study.

The amounts of TNF- $\alpha$ were also compared in both groups in the same manner as described for IFN- $\gamma$. As seen in Figure 1 , LAK cells produced by three different stimulation conditions secreted no more than $420 \pm 300 \mathrm{pg} / \mathrm{ml}$ of TNF in normal individuals, whereas in TB patients, the average TNF- $\alpha$ levels in unstimulated and stimulated cells were around 2000-3500 $\mathrm{pg} / \mathrm{ml}$. These results indicate that TB patients produce significantly higher levels of TNF- $\alpha$ than do normal individuals $(p<$ $0.01)$. On coculturing the prestimulated cells overnight with target U937 cells at a stimulator/effector ratio of 2:1, there was a substantial increase in cytokine production in normal individuals. It was found that $200-2000 \mathrm{pg} / \mathrm{ml} \mathrm{TNF}-\alpha$ was produced in response to prestimulation with IL-2 + IL-12, but when IL-12 alone was used, the response was not so dramatic. The levels dropped to $15-90 \mathrm{pg} / \mathrm{ml}$, indicating that by itself IL-12 was unable to prestimulate the cells to induce them to produce TNF$\alpha$ in response to the target cells. There was, however, no TNF production in response to tumor targets among the TB patients even after prestimulation with the cytokines. Therefore, it is clear that there was a significant reduction in the secretion of TNF- $\alpha$ by TB patients in response to tumor targets $(p<0.001)$ compared with normal individuals. In mycobacterial infection, TNF- $\alpha$ is required for control of bacillary growth and the protective granulomatous response, but it may cause an immunopathologic condition. Results from experiments using murine models suggest that the relative amount of TNF- $\alpha$ at the site of infection determines whether the cytokine is protective or destructive. ${ }^{(19)} \mathrm{TNF}-\alpha$ is even implicated in the synergism between $M$. tuberculosis and HIV infection. ${ }^{(20,21)}$ The role 


$\square \begin{aligned} & \text { NORMAL } \\ & \text { LAK }\end{aligned} \underset{\text { COCULTURE }}{\text { TB }} \quad \square$ LAK $\quad \square \quad \begin{aligned} & \text { TB } \\ & \text { COCULTURE }\end{aligned}$

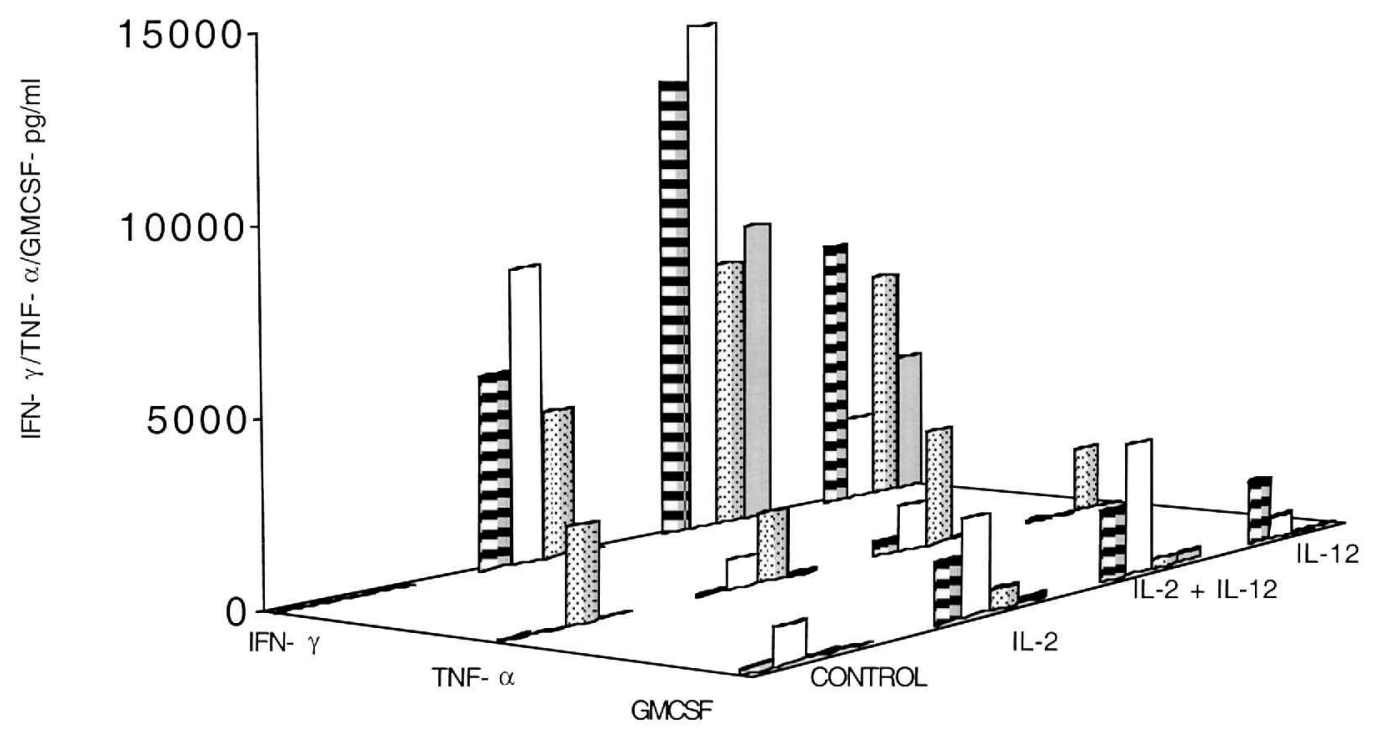

FIG. 1. Comparison of cytokine (IFN- $\gamma / \mathrm{TNF}-\alpha / \mathrm{GM}-\mathrm{CSF}$ ) production by LAK cells in response to stimulation by different cytokines (control/IL-2/IL-2+IL-12/IL-12) in normal individuals and TB patients, respectively. Comparison of cytokine production after LAK coculture with U937 target cells in normal individuals and TB patients, respectively $(n=8)$. Data are expressed as mean \pm SD for each category. IFN- $\gamma$ production by LAK cells in response to a combination of IL- $2+$ IL-12 was significantly greater compared with each cytokine alone $(p<0.01)$ and significantly lower in TB patients than in normal individuals $(p<$ $0.05)$. In response to tumor targets, the levels were significantly greater in normal individuals than in TB patients $(p<0.001)$. TNF- $\alpha$ production by LAK cells in TB patients was significantly higher than in normal individuals $(p<0.01)$. Coculturing with tumor targets yielded opposite results, with TB patients showing significantly lower values $(p<0.001)$. GM-CSF production by LAK cells in response to three different stimulations in normal individuals was significantly higher than in TB patients $(p<$ $0.05-0.01)$. In normal individuals, it increased substantially after LAK coculture with U937 target cells $(p<0.01)$ and was significantly higher compared with levels in TB patients $(p<0.001)$.

of TNF- $\alpha$ is intriguing and needs to be further investigated before the complexities of the web of cytokine regulation of $\mathrm{T}$ cell function can be untangled.

GM-CSF was assessed in the same fashion as IFN- $\gamma$ and TNF- $\alpha$. As seen in Figure 1, LAK cells produced by three different stimulations secreted around $2500 \mathrm{pg} / \mathrm{ml} \mathrm{GM-CSF}$ in normal individuals and no more than $50-500 \mathrm{pg} / \mathrm{ml}$ in TB patients $(p<0.05-0.01)$. On coculturing the prestimulated cells overnight with target U937 cells at a stimulator:effector ratio of $2: 1$, there was a substantial increase in cytokine production in normal individuals compared with the LAK values $(p<$ 0.01 ). It was found that $200-2000 \mathrm{pg} / \mathrm{ml} \mathrm{GM-CSF}$ was produced in response to prestimulation with IL-2 and IL-12, but when IL-12 alone was used, the response was not so dramatic. The levels dropped to $15-90 \mathrm{pg} / \mathrm{ml}$, indicating that by itself IL12 is unable to prestimulate the cells to a great extent to induce them to produce GM-CSF in response to the target cells. There was, however, no GM-CSF production in response to tumor targets among the TB patients even after prestimulation with the cytokines compared with normal individuals $(p<0.001)$.

Unstimulated PBMCs could not be activated by the allogeneic tumor cell line to release cytokines, as seen from the control values, and target cells did not produce these cytokines when cultured alone (data not shown).

These data indicate that the interaction between LAK cells and tumor cells causes a large increase in the production of cytokines with known cytotoxic potential in normal individuals. However, the secretory functions of effector cells in TB patients were found to be significantly altered. It is possible that in vivo also the effector population of TB patients shows diminished secretory functions in response to the presence of infected macrophages. Decreased cytokine induction by PBLs in response to $M$. tuberculosis infection may lead to diminished macrophage activation and a more permissive environment for the bacteria. Patients with active TB manifest reduced activity at the T cell, monocyte, and NK cell levels compared with normal individuals. This is probably due to the decreased induction of cytokines by TB patient cells in response to mycobacterial infection.

From these results, one can speculate that the effector populations of TB patients are in a state of target-induced anergy and, hence, do not respond in an appropriate manner. This can, however, be overcome to a large extent by a combination of the two cytokines IL-2 and IL-12. Knowledge of the cytokine response to infectious diseases is important in understanding the immune basis of the host response. ${ }^{(15)}$ Major players have emerged, and immunotherapy aimed at manipulating these has already shown promise..$^{(22-24)}$ The current challenge is to master the art of navigating the fine line between protection and pathology in TB. ${ }^{(25,26)}$ 


\section{ACKNOWLEDGMENTS}

This work was supported by a fellowship grant from the Indian Council of Medical Research (ICMR), Delhi, India. The help and cooperation rendered by the scientific, technical, administrative, and other support staff of the Tuberculosis Research Centre (ICMR), Chennai, India, at all times, is acknowledged with a deep sense of gratitude.

\section{REFERENCES}

1. WORLD HEALTH ORGANIZATION. (1990). Tuberculosis Control Program: Progress and evaluation report EB87/4. Geneva: WHO.

2. YOUMANS, G.P. (1979). Tuberculosis. Philadelphia: W.B. Saunders.

3. JOHNSON, B.J., and McMURRAY, D.N. (1994). Cytokine gene expression by cultures of human lymphocytes with autologous $M y$ cobacterium tuberculosis-infected monocytes. Infect. Immun. 63, 1444-1450.

4. ROILIDES, E., and PIZZO, P.A. (1992). Modulation of host defenses by cytokines: adjuvants in prevention and treatment of serious infection in immunocompromised hosts. Clin. Infect. Dis. 15, $508-524$

5. ORME, I.M. (2000). Tuberculosis: recent progress in basic immunity and vaccine development. Kekkaku 75, 97-101.

6. LIN, Y., ZHANG, M., HOFMAN, F.M., GONG, J., and BARNES, P.F. (1996). Absence of a prominent Th2 cytokine response in human tuberculosis. Infect. Immun. 64, 1351-1356.

7. WAKEHAM, J., WANG, J., MAGRAM, J., CROITORU, K., HARKNESS, R., DUNN, P., ZGANIACZ, A., and XING, Z. (1998). Lack of both types 1 and 2 cytokines, tissue inflammatory responses, and immune protection during pulmonary infection by Mycobacterium bovis bacilli Calmette-Guérin in IL-12-deficient mice. J. Immunol. 160, 6101-6111.

8. XING, Z. (2000). Current understanding of macrophage type $1 \mathrm{cy}$ tokine responses during intracellular infections. Histol. Histopathol. 15, 199-205.

9. ROTTENBERG, M.E., GIGLIOTTI ROTHFUCHS, A., GIGLIOTTI, D., CEAUSU, M., UNE, C., LEVITSKY, V., and WIGZELL, H. (2000). Regulation and role of IFN-gamma in the innate resistance to infection with Chlamydia pneumoniae. J. Immunol. 164, 4812-4818.

10. ARANCIA, G., STRINGARO, A., CRATERI, P., TOROSANTUCCI, A., RAMONI, C., URBANI, F., AUSIELLO, C.M., and CASSONE, A. (1998). Interaction between human interleukin-2activated natural killer cells and heat-killed germ tube forms of Candida albicans. Cell. Immunol. 186, 28-38.

11. KIM, K.H., LEE, Y.S., JUNG, I.S., PARK, S.Y., CHUNG, H.Y., LEE, I.R., and YUN, Y.S. (1998). Acidic polysaccharide from Panax ginseng, ginsan, induces Th1 cell and macrophage cytokines and generates LAK cells in synergy with rIL-2. Planta Med. 64, $110-115$

12. PHILLIPS, J.H., and LANIER, L.L. (1986). Dissection of the lymphokine-activated killer phenomenon. J. Exp. Med. 164, 814-825.

13. GONG, Y.H., GUO, X., and ZHANG, X.Q. (1994). Immunoelectron microscopic studies on the process of tumor cytolysis mediated by lymphokine-activated NK cells. Chung Hua Ping Li Hsueh Tsa Chih 23, 17-19.

14. BONAVIDA, B., KATZ, J., and GOTTLIEB, M. (1986). Mechanism of defective NK cell activity in patients with acquired immunodeficiency syndrome (AIDS) and AIDS-related complex1. Defective trigger on NK cells for NKCF production by target cells, and partial restoration by IL-2. J. Immunol. 137, 11571163.

15. MENDES, R., BROMELOW, K.V., WESTBY, M., GALEALAURI, J., SMITH, I.E., O'BRIEN, M.E., and SOUBERBIELLE, B.E. (2000). Flow cytometric visualization of cytokine production by CD3-CD56 ${ }^{+} \mathrm{NK}$ cells and $\mathrm{CD} 3{ }^{+} \mathrm{CD} 56^{+} \mathrm{NK}-\mathrm{T}$ cells in whole blood. Cytometry 39, 72-78.

16. FRESNO, M., KOPF, M., and RIVAS, L. (1997). Cytokines and infectious diseases. Immunol. Today 18, 56-58.

17. ANITA, S., CHONG, F., SCUDERI, P., GRIMES, W.J., and HERSH, E.M. (1989). Tumor targets stimulate IL-2 activated killer cells to produce interferon-gamma and tumor necrosis factor. J. Immunol. 142, 2133-2139.

18. NEW ZHANG, M., GATELY, M.K., WANG, E., GONG, J., WOLF, S.F., LU, S., MODLIN, R.L., and BARNES, P.F. (1994). Interleukin 12 at the site of disease in tuberculosis. J. Clin. Invest. 93, 1733-1739.

19. BEKKER, L.G., MOREIRA, A.L., BERGTOLD, A., FREEMAN, S., RYFFEL, B., and KAPLAN, G. (2000). Immunopathologic effects of tumor necrosis factor alpha in murine mycobacterial infection are dose dependent. Infect. Immun. 68, 6954-6961.

20. LAWN, S.D., RUDOLPH, D., WIKTOR, S., COULIBALY, D., ACKAH, A., and LAL, R.B. (2000) Tuberculosis (TB) and HIV infection are independently associated with elevated serum concentrations of tumour necrosis factor receptor type 1 and beta 2 -microglobulin, respectively. Clin. Exp. Immunol. 122, 79-84.

21. IMPERIALI, F.G., ZANINONI, A., LA MAESTRA, L., TARSIA, P., BLASI, F., and BARCELLINI, W. (2001). Increased $M y$ cobacterium tuberculosis growth in HIV-1-infected human macrophages: role of tumour necrosis factor-alpha. 1. Clin. Exp. Immunol. 123, 435-442.

22. PULASKI, B.A., CLEMENTS, V.K., PIPELING, M.R., and OSTRAND-ROSENBER, S. (2000). Immunotherapy with vaccines combining MHC class II/CD80 ${ }^{+}$tumor cells with interleukin-12 reduces established metastatic disease and stimulates immune effectors and monokine induced by interferon gamma. Cancer Immunol. Immunother. 49, 34-45.

23. AADDIN, H., LARSEN, C.S., MOLLER, B.K., ULLUM, H., BUHL, M.R., GERSTOFT, J., SKINHOI, P., and PEDERSEN, B.K. (2000). Effects of subcutaneous interleukin-2 therapy on phenotype and function of peripheral blood mononuclear cells in human immunodeficiency virus-infected patients. Scand. J. Immunol. 51, 168-175.

24. YOON, S.J., HEO, D.S., KANG, J.O., and KIM, N.K. (1999). Combination gene therapy of IL-12 and allogeneic MHC class I gene via stimulating NK cytolytic activity. Anticancer Res. 19, 4337-4342.

25. POWRIE, F., and COFFMAN, R.L. (1993). Cytokine regulation of T-cell function: potential for therapeutic intervention. Immunol. Today 14, 270-274.

26. EHLERS, S., MIELKE, M.E.A., and HAHN, H. (1994). Progress in TB research: Robert Koch's dilemma revisited. Immunol. Today $15,1-4$.

Address reprint requests to:

Dr. P.R. Narayanan

Director, Tuberculosis Research Center

Mayor V.R. Ramanathan Road, Chetput, Chennai-600031

India

Tel: $+91-44-8265403$

Fax: +91-44-8228894

E-mail: prnarayanan@vsnl.com

Received 12 September 2001/Accepted 5 February 2002 